\title{
Dançarinos de quadrilha junina: um divertimento que é trabalho?
}

\author{
Natália Bezerra da Silva ${ }^{\mathrm{I}, 1}$, Thelma Maria Grisi Velôso ${ }^{\mathrm{II}, 2}$, \\ Francinaldo do Monte Pinto ${ }^{\mathrm{II}}, 3$ \\ ${ }^{\mathrm{I}}$ Centro de Referência da Assistência Social (Brejo da Madre de Deus, PE, Brasil) \\ ${ }^{\text {II }}$ Universidade Estadual da Paraíba (Campina Grande, PB, Brasil)
}

\begin{abstract}
Nos festejos juninos de Campina Grande, PB, conhecidos como "O maior São João do mundo", as quadrilhas juninas são consideradas um grande ícone da festa. A partir de uma pesquisa realizada com dançarinos de quadrilha dessa cidade, nos ocuparemos, neste artigo, das representações sociais que são construídas sobre essa atividade. Foram realizadas, além da observação participante, vinte entrevistas semiestruturadas com dançarinos de ambos os sexos, das quadrilhas Arraial da Felicidade e Mistura Gostosa. A análise dos dados, operada pelo método hermenêutico-dialético, evidenciou que os dançarinos de quadrilhas juninas constroem diferentes representações sobre essa atividade: divertimento, lazer, prazer, responsabilidade e trabalho. Por fim, observou-se que os entrevistados constroem um discurso que enfatiza os efeitos positivos dessa atividade, o reconhecimento social, o entrosamento coletivo e a realização pessoal.
\end{abstract}

Palavras-chave: Representações sociais, Dançarinos de quadrilha junina, Trabalho.

June square dance revelers: is this work or entertainment?

In June revels in Campina Grande/PB, "The Greatest São João in the World”, square dance groups of revelers are considered the greatest hits of the revels. A research carried out among the June square dance groups in this city is the subject of this article, the social representations constructed around this activity. Besides the participating observations, twenty semi-structured interviews were carried out among dancers of both sexes, members of the groups "Arraial da Felicidade", and "Mistura Gostosa". The data analysis was performed using the hermeneutical-dialectical method and the result shows that June square dance revelers construct different representations about this activity: entertainment, leisure, pleasure, responsibility and professional work. It was concluded that the subjects interviewed make up a discourse that stresses the positive effects of this activity, such as social recognition, collective understanding and personal fulfillment.

Keywords: Social representations, June square-dance revelers, Work.

\section{Introdução}

T o espaço urbano, os festejos juninos perderam o seu lado concreto de festa rural, exemplo de manifestação cultural, religiosidade popular e festa da tradição, e instituíram-se como "uma produção prática e discursiva, imagética e cênica, a qual toma a ideia de tradição como principal e fundamental enunciado e elemento definidor do evento junino" (Lima, 2008, p. 21).

As quadrilhas juninas são consideradas por autores como Carvalho (2008) e Lima (2008) o grande ícone e símbolo de um grande evento, realizado em Campina Grande -PB, em comemoração aos festejos juninos, denominado "O maior São João do mundo". Outros elementos constitutivos da festa, como a fogueira, os balões e as bandeiras multicolores, ajudam na composição desse evento, mas a quadrilha junina é, definitivamente, o seu grande símbolo, de tal maneira que não existe festa junina sem a participação de quadrilhas juninas. "É ela, inclusive, que ajuda a criar e a instituir todo o imaginário em torno da festa junina como uma festa matuta, através, por exemplo, de sua indumentária e vestuário" (Lima, 2008, p. 114, grifo da autora).

No caso específico da cidade de Campina Grande, assinala a referida autora, as quadrilhas ganham ainda mais destaque, pois foram elas que deram o incentivo inicial para a construção paulatina dos chamados "festejos de rua". As quadrilhas juninas contribuem, ainda, para a instituição do imaginário da festa como um evento inocente, ingênuo, uma festa primitiva e exótica com um misto de humor e de simplicidade. 
Afirma Trigueiro (2007) que as quadrilhas "são manifestações culturais contemporâneas (re) significadas para atender às demandas de consumo da sociedade midiatizada, em que se misturam as experiências tradicionais modernas" (p. 1). Essa atividade se encontra, portanto, em meio a todo um jogo de interesses que se apresenta mascarado sobre um discurso de busca e preservação das tradições da cidade. Diante desse cenário, realizamos uma pesquisa que analisou as representações sociais construídas por dançarinos de quadrilha sobre a participação deles nessa atividade.

Partimos do conceito de representação social como um conhecimento produzido pelo senso comum, compartilhado e articulado, que se constitui em uma teoria leiga a respeito de determinados objetos sociais e que está intimamente ligado à construção das identidades (Guareschi, 1996; Oliveira \& Werba, 1998), estas, por sua vez, constituídas a partir das várias inter-relações que interpelam os sujeitos e caracterizadas como múltiplas e mutáveis (Ciampa, 1984, 2008).

A pesquisa ${ }^{1}$ foi realizada com dançarinos de duas quadrilhas juninas de Campina Grande, a quadrilha tradicional Arraial da Felicidade e a quadrilha estilizada Mistura Gostosa², ambas filiadas à Associação de Quadrilhas Juninas de Campina Grande (ASQUAJU - CG).

De acordo com a Secretaria de Educação, Esporte e Cultura de Campina Grande, existe cerca de 150 quadrilhas registradas. Com o intuito de delimitar nosso universo de pesquisa, foram definidos alguns critérios. Assim, a quadrilha estilizada Mistura Gostosa se destacou entre as demais por ter sido a que recebeu mais vezes o título de campeã no concurso de quadrilhas de Campina Grande, no total de 4 colocações em primeiro lugar; por estar associada à ASQUAJU e por se encontrar, no momento da coleta dos dados, com 15 anos de existência. A Arraial da Felicidade, uma quadrilha tradicional, destacou-se por ser vinculada à ASQUAJU desde sua fundação, mas nunca ter participado do concurso de quadrilhas de Campina Grande; e por estar, no momento da coleta dos dados, com 35 anos de existência.

Foram realizadas vinte entrevistas, dez com cada uma das quadrilhas. Foram entrevistados cinco mulheres e cinco homens em cada uma. Os participantes das quadrilhas são adolescentes ou adultos jovens, sendo assim, a faixa etária variou entre 15 e 24 anos. A maioria dos entrevistados se definiu como solteiro, apenas uma entrevistada era casada. $O$ grau de estudo variou entre ensino fundamental completo e nível superior completo, porém a maior parte havia cursado o ensino médio. $\mathrm{O}$ tempo de quadrilha dos entrevistados variou entre 1 e 15 anos.

Os entrevistados foram escolhidos pelo critério de acessibilidade, isto é, foram entrevistados os dançarinos(as) das referidas quadrilhas, que se colocaram à disposição para participar da pesquisa. O número de entrevistas foi definido pelo critério do "ponto de saturação". Nesse sentido, a análise dos dados acompanha todo o processo de desenvolvimento da pesquisa, e o ponto de saturação é atingido quando se dispõe de informações suficientes sobre determinado aspecto que está sendo analisado (Lang, Campos \& Demartini, 2010; Sá, 1996).

Além das entrevistas, foi realizada a observação participante, que ficou organizada em torno de dez visitas, divididas da seguinte forma: uma entrevista a cada um dos ensaios das duas quadrilhas pesquisadas, e duas, no dia da apresentação das quadrilhas, a Arraial da Felicidade se apresentou na Federação das Indústrias do Estado da Paraíba (FIEP), e a Mistura Gostosa se apresentou no Parque do Povo, durante o concurso de quadrilhas juninas de Campina Grande. Foram realizadas, ainda, quatro visitas nas reuniões da ASQUAJU - CG, e duas observações de ensaios de outras quadrilhas estilizadas, as quadrilhas Arraial da Alegria e Trilha Junina. Vale

1 Esta pesquisa foi aprovada pelo Comitê de Ética em Pesquisa.

2 Alguns coordenadores de quadrilhas classificam-nas em estilizadas e tradicionais e afirmam que a principal diferença está no fato de a quadrilha tradicional ter um puxador, que é a pessoa encarregada de direcionar os passos a serem realizados durante a apresentação da quadrilha junina, e os passos realizados serem os ditos passos tradicionais, que incluem balancê, cestinha de flores, alavantu, anarriê (Comunicação pessoal, 31 de março de 2009). 
destacar que estas duas últimas observações foram realizadas antes da delimitação do universo de pesquisa.

A análise das entrevistas foi guiada pelo método hermenêutico-dialético proposto por Minayo (1996), que afirma que esse método possibilita uma interpretação que "coloca a fala em seu contexto para entendê-la a partir do seu interior e no campo da especificidade histórica e totalizante em que é produzida" (p. 231).

\section{"Ser" dançarino de quadrilha: divertimento, trabalho, prazer}

Nas entrevistas realizadas, as representações construídas pelos dançarinos vinculam essa atividade ao divertimento e ao trabalho. Diante disso, buscamos inspirações nas Clínicas do Trabalho, notadamente na Ergologia e na Psicodinâmica do Trabalho, que, apesar de suas diferenças, têm em comum o fato de estudar a atividade humana de trabalho. A noção de atividade sinaliza uma ação, "um impulso de vida, de saúde, sem limite predefinido, que sintetiza, cruza e liga tudo o que se representa separadamente (corpo/espírito; individual/coletivo; privado/ profissional)" (Durrive \& Schwartz, 2008, p. 23).

A atividade dos dançarinos de quadrilhas juninas, expressão do folclore nordestino, é representada, neste estudo, por diferentes construções de sentidos atravessados pela dança, como: divertimento, responsabilidade, lazer, prazer, trabalho, sofrimento e preconceito. De modo geral, o agrupamento desses sentidos/representações mobilizados pela dança remete à tentativa permanente do viver junto, de partilhar as conquistas e de superar os obstáculos vivenciados na quadrilha, na busca da noção do bem comum.

\section{Lazer/diversão/prazer $x$ trabalho}

Em seus relatos, alguns dançarinos afirmaram que um dos fatores que os levaram a participar da quadrilha junina foi o fato de lhes proporcionar momentos de diversão, de lazer:

É mais assim um significado... por eu gostar, é... é um... é um tipo assim um respeito que eu tenho, mas essa parte de quadrilha assim na minha vida é mais como diversão, porque eu estudo tanto, durante o ano todo, e assim o mês de junho eu decidi dançar quadrilha pra ser como uma forma de diversão, de lazer [enfatiza] porque eu não tenho momentos de lazer durante o ano, é mais uma forma de divertimento mesmo a quadrilha.

Entrevistadora: Como é esse divertimento?

Durante as apresentações, primeiramente começando nos ensaios, porque os ensaios começaram agora no mês de janeiro, aí... novas amizades fazemos, porque... nem sempre ficam os mesmos dançarinos do ano anterior, entram novas pessoas, então já são novos amigos que você vai fazer, construir novas amizades, antes de começar os ensaios, eles ligam lá o som... fica a turma conversando e tudo isso é uma forma assim de descontrair, uma forma de não... não continuar na mesmice, que no caso é durante a semana com meus estudos. No início é só no fim de semana os ensaios, sexta, sábado e domingo, mas como agora que tá chegando perto é todos os dias, e é uma forma de divertimento pra mim, eu passo o dia na faculdade estudando e à noite eu vou pro ensaio esquecer um pouco daquela... do meu dia... meio turbilhante que foi... e é isso, conversas, risadas e durante o mês mesmo [enfatiza] 
de junho são as apresentações, lugares novos que conhecemos, amizades novas que fazemos e tudo isso pra mim é uma forma de lazer, de divertimento (Corina, 20 anos, $\mathrm{MG}^{3}$ ).

e hoje pra mim é minha diversão, porque, como eu tava trabalhando, como a gente trabalha muito, chega em casa cansado, não tem tempo pra se divertir, e eu... tenho a quadrilha como meu lazer, todo ano a gente tira esse período junino do São João, pra se divertir por aí, conhecer outros lugares.

Entrevistadora: Então hoje é o seu lazer?

Hoje é o meu lazer, e é o que eu gosto de fazer, pra mostrar a cultura das cidades da Paraíba e Campina Grande.

Entrevistadora: E como é esse gostar de fazer?

É... é você ter prazer e fazer uma coisa que você gosta, pois... a [pausa] quando eu morava lá no bairro, não tinha nenhuma diversão, a única diversão que a gente tinha era realmente a quadrilha, que justamente era onde reunia os amigos, pra poder a gente se ver, se divertir. Aí a quadrilha nesse momento que eu gostei mesmo, que eu vi então que era o que eu queria, e até então da Mistura Gostosa... lá eu só fazia dançar, na Mistura Gostosa eu entrei mais de dentro mesmo da quadrilha, e hoje eu faço, eu ajudo lá os meninos numa coreografia numa opinião, hoje em dia é um hobby pra mim.

...

Entrevistadora: E que significado tem pra você o fato de ser dançarino de quadrilha? O que isso significa na sua vida?

Pra mim significa assim... porque... primeiramente vem minha vida pessoal, meu trabalho, e... meu relacionamento familiar, amoroso, e tudo mais, mas, pessoalmente assim, só pra satisfazer a minha... vontade de dançar e... o meu ego maior, né? é muito bom, pra quem, pra quem gosta mesmo, é uma diversão muito boa, tem que gostar muito pra aproveitar mesmo, e... eu gosto, isso aqui é a minha diversão. (José, 23 anos, MG).

Isso, porque... São João, até antes de São João, a gente... ensaia uns meses antes, isso é o meu lazer à noite, eu encaro como isso, sabe? como um... um lazer, de dançar quadrilha, trabalha o dia todinho, quando chega a noite, vou ali, vou, meu lazer é isso, dançar quadrilha (Biu, 22 anos, AF).

Nos discursos anteriores, os entrevistados representaram a atividade de dançarinos de quadrilha como uma forma de diversão não vivenciada no trabalho. Neste caso, como enunciado por Corina e José, o lazer e o divertimento são sinônimos, apesar de não serem vivenciados simultaneamente no trabalho. Ora, a diversão, concebida no sentido de festa, "é por definição, o oposto do trabalho. Ela sempre marca o desejo de renovação, o tempo em que se pode deixar levar, não ser sério ... Enfim, deixar o racional da vida cotidiana para se entregar ao irracional, ao emocional e aos excessos" (Enriquez, 2014, p. 170).

As representações convergem para uma separação entre lazer/divertimento e trabalho. Nesse caso, o lazer proporcionado pela quadrilha parece estar desvinculado de algum tipo de trabalho. Lazer, aqui, é diferente (não o contrário) de trabalho.

Em princípio, a quadrilha não recebe o status de trabalho. De um lado, ela opera como um espaço livre de mobilização do corpo, da criatividade, do prazer e do viver junto; de outro, o engajamento dos dançarinos na quadrilha sinaliza a ausência de prazer em seu trabalho, dando a entender que o trabalho é dominado pelo desgaste físico.

3 Para garantir o anonimato dos entrevistados, os nomes deles foram substituídos por pseudônimos. Em seguida, vem a idade do entrevistado e as siglas MG ou AF, que servirão para designar as quadrilhas entrevistadas, significando, respectivamente, Mistura Gostosa e Arraial da Felicidade. 
Aquino e Martins (2007) afirmam que, já na Grécia Antiga, os conceitos de ócio e de trabalho eram antagônicos. Porém, nessa época, o ócio "era uma condição de liberdade relativa à necessidade de trabalhar" (p. 9). Depois da Revolução Industrial, o tempo livre passou a ser configurado como conquista social da classe proletária. Diante da exploração do capital, o lazer se institui como um direito social.

A dicotomia estabelecida entre lazer e trabalho remete a uma visão de trabalho destituída de prazer. Mas, afinal, é o trabalho mesmo que não oferece prazer a quem o realiza? Não seria o caso de atribuirmos às condições e à organização do trabalho, isto é, ao modo como são fixados os objetivos, as regras, a divisão de tarefas e responsabilidades, como um dos fatores que im(possibilita) o prazer no trabalho?

Cumpre ainda ressaltar que o divertimento, nas entrevistas, ainda se encontra associado ao prazer despertado pela dança em si, como atividade rítmica. Por outro lado, para esses entrevistados, a escolha de ser dançarino de quadrilha está associada a algum tipo de identificação com a dança, independentemente de seu ritmo.

Em alguns discursos, ainda encontramos referência à satisfação em realizar apresentações por meio das referidas quadrilhas, em viajar, conhecer novos lugares e pessoas.

Foi... é algo... é algo que eu gosto, apesar que eu gosto de dança, adoro dançar, gosto muito, e quando você conhece, tem novas amizades, você conhece muitos estados, você viaja muito, e é muito bom, eu, eu gosto (João, 19 anos, MG).

Porque eu gosto de dança, e gosto de dança de todo tipo, sabe? Comecei desde pequena, dançando em escola, aí comecei a fazer dança de salão, já fiz dança do ventre (Zefinha, 22 anos, AF).

Eu acho que porque... é a dança, né? em si? A dança é muito bom, você tá dançando, escutando aquela música bem... A batida, você sente aquele negócio (ininteligível). Ai terminou pegando e eu não pretendo deixar tão fácil. (Pedro, 24 anos, MG).

Porque eu gosto muito de dançar, assim, admiro muito, acho muito lindo, é uma coisa muito especial pra mim, gosto demais, nunca, eu só vou deixar a quadrilha quando... dizer assim: "acabou", aí eu saio. (Detinha, 17 anos, AF).

A análise dessas representações denota o sentido da dança, desde os tempos primitivos, como essencialmente um conjunto de gestos e movimentos regidos por uma necessidade de padronização específica (de normas, coreografias, passos e batidas) que serão executados em um espaço e tempo determinados pelo ritmo individual e coletivo do(s) dançarino(s) (Rangel \& Mommensohn, 1991 citado por Fernandes, 2011).

No caso das quadrilhas juninas, percebe-se que o entusiasmo pela dança, embalada pela sonoridade musical, ritmada pelos gestos e pelos movimentos na quadrilha, produz significados, às vezes indecifráveis aos dançarinos, sobre a magia da dança em apresentações de quadrilhas juninas. A complexa relação entre gesto e movimento, postulada por Leplat (2013), remete ao entendimento de que o movimento de uma pessoa adquire o estatuto de gesto quando ela lhe atribui um significado. Em outros termos, um gesto pode ser considerado movimento à proporção que os humanos encontrarem significados.

Os entrevistados relatam que sentem prazer em dançar quadrilha e se realizam durante as apresentações, como podemos observar a seguir:

Entrevistadora: E por que você escolheu ser dançarina de quadrilha? 
Porque assim, é muito gostoso você tá ali se apresentando, você tá fazendo o melhor possível, as pessoas lhe observando, apreciando ali aquele espetáculo, porque hoje em dia a quadrilha tá muito diferente do que era antigamente. (Lena, 20 anos, MG).

Entrevistadora: E como você se sente quando você está dançando? O que é que você sente?

Eu sinto prazer.

Entrevistadora: Prazer?

É.

Entrevistadora: Como é esse prazer?

É uma emoção muito grande, eu espero que você venha aqui, assistir a apresentação da gente no domingo, toda vez que a gente se apresenta aqui, vem o povo todo, êita [enfatiza] é muito bom, muito bom mesmo, é... (Antônio, 23 anos, AF).

Assim... é... eu fico... fico emocionada [enfatiza], chego até a casos assim, como na nossa primeira apresentação que sempre é no bairro, não tem uma única quadrilha [enfatiza] que não chore, na primeira apresentação, porque a gente vê o esforço que nós tivemos durante, de cinco a seis meses ensaiando, ensaiando, chegando tarde em casa, e isso é uma motivação muito grande pra um dançarino que gosta do que faz [enfatiza]. (Corina, 20 anos, MG).

É, é uma realização, pra gente que passa por dificuldades pra... ter um vestido, pra comprar um vestido, porque hoje em dia como as quadrilhas evoluíram muito o figurino também evoluiu muito... né? Então a gente trabalha e passa, trabalha o dia todinho aí tem um dinheiro ali, quer ir prum canto, mas não, guarda, porque já é alguma coisa pra quadrilha..., né? Passa pelo esforço e dificuldade de juntar trinta e dois pares, é... trinta e duas cabeças pensando diferente pra chegar num acordo, mas quando a gente... a nossa primeira apresentação, quando todo mundo se veste, que tá todo mundo assim com um olhinho brilhando, um olhando um pro outro, dizendo chegou a hora [enfatiza], você esquece tudo e você se realiza [enfatiza], de ver aonde você vai dançar, um Arraial lotado aplaudindo... chamando o nome da quadrilha, é uma realização (Joana, 22 anos, MG).

Observemos nesses relatos a ênfase ao prazer proporcionado pela atividade. $O$ prazer de se apresentar para o público e obter reconhecimento. Eles dizem se sentirem realizados e, nesse momento, todos os esforços e dificuldades são relativizados.

Por outro lado, como explicitado anteriormente, não se pode desconsiderar que as quadrilhas são manifestações culturais que procuram atender às necessidades da sociedade de consumo e midiatizada (Trigueiro, 2007). Lena, ao definir a apresentação como um espetáculo, "apreciando ali aquele espetáculo, porque hoje em dia a quadrilha tá muito diferente do que era antigamente", nos remete às discussões de alguns autores sobre a sociedade da imagem ${ }^{4}$. Nessa sociedade se vive em meio a uma cultura dominada por imagens onde a mídia desempenha um papel fundamental, pois cria narrativas que formam um universo de "ilusões" para os sujeitos. ○ "espetáculo" exposto na mídia atinge diversas esferas sociais e produz "uma realidade à parte", ou um "hiper-real" Nessa sociedade, tudo vira espetáculo e, consequentemente, tudo o que vira espetáculo passa a ser consumido.

\section{Diversão com responsabilidade}

4 O conceito de sociedade da imagem, ou sociedade do espetáculo, remonta à década de 1960, na França, por meio das formulações de Guy Debord. Essa é mais uma denominação da sociedade de consumo, em que se enfatiza a relação da imagem com o capitalismo (Belloni, 2003; Fridman, 2009).

5 As expressões "uma realidade à parte" e "hiper-real" são utilizadas aqui a partir de Baudrillard (1997 citado por Fridman, 2009). 
A diversão proporcionada pela quadrilha também é apresentada como algo realizado de modo responsável, devido às regras existentes dentro das quadrilhas, como o compromisso com os ensaios e os horários a seguir, como podemos observar nas falas a seguir:

Entrevistadora: E por que você escolheu ser dançarino de quadrilha?

[Silêncio]

Porque eu escolhi... é uma ótima pergunta, visse? Primeiro... por... assim, tipo uma diversão [enfatiza].

Entrevistadora: Tipo uma diversão?

É uma diversão, assim, devido ao São João, devido às tradições, né? de antigamente.

Entrevistadora: Devido às tradições?

É, devido às tradições, e... objetivo assim [pausa] é uma diversão com responsabilidades, tem a responsabilidade, tem outras diversões, essas festas assim, mas a quadrilha mesmo é uma diversão [enfatiza] totalmente diferente totalmente diferente dessas outras festas, porque a quadrilha, a gente começa um ano antes, aí já vem...

Entrevistadora: É uma diversão diferente?

Aí já é diferente, porque você conhece pessoas novas, culturas novas, é... convive mais tempo com o pessoal, e essas outras festas assim paralela é só aquele dia... aí pronto, acabou, não tem mais [pausa] é só isso, por diversão mesmo (Tião, 22 anos, MG).

Entrevistadora: E que significado isso tem na sua vida, o fato de ser dançarino?

Vou the ser bem sincero, é... como eu lhe falei logo no início, pra mim tem essa questão da... da responsabilidade de defender a cultura, de mostrar a nossa cultura, mas é o significado de diversão, tá entendendo? Com um pouco de responsabilidade, não tanto [enfatiza], com um pouco de responsabilidade, mas pra mim, é um significado de diversão.

Entrevistadora: Com um pouco de responsabilidade?

Assim, em relação para com a quadrilha, né? Aquela regra, porque todo, todo lugar tem uma regra, é igual a uma sala de aula, tem uma regra pro aluno, né isso? [risos] Aí pronto, pra mim, na, na minha visão é uma... um divertimento com responsabilidade, com um pouco de responsabilidade que a gente gosta, né? (Bento, 23 anos, MG).

Percebe-se, nessas falas, que a representação da atividade de dançarino se faz presente pela via da diversão com responsabilidade, justificada por regras e critérios predeterminados, partilhados coletivamente na quadrilha. O trabalho coletivo é possível pelo agrupamento das experiências singulares, com a finalidade de construir uma dinâmica coletiva comum, em que prevalecem os elos que os humanos fabricam com o propósito de trabalhar, através da cooperação, por meio de uma atividade específica denominada deontologia do fazer (Dejours, 2012).

Esse modo de fazer e de viver juntos o acontecimento "quadrilha" mobiliza o desejo dos dançarinos de cooperarem para a construção de uma obra comum. Todavia essa cooperação não os exime do compromisso de cumprir regras e de assumir responsabilidades perante o grupo. Como assinala Dejours (2012), "a cooperação é com certeza um poderoso dispositivo de estruturação das ligações de ajuda mútua, solidariedade e harmonia” (p. 113).

\section{O preconceito/vagabundagem}

Os relatos também evidenciam o preconceito que os dançarinos vivenciam, observemos a seguir: 
Entrevistadora: Que significado tem na tua vida, que importância tem pra você ser dançarino de quadrilha?

Quadrilha [pausa] como é que eu explico...

[Silêncio]

Entrevistadora: É importante?

Pra mim é [enfatiza]... é importante sim.

Entrevistadora: Por que é importante?

Porque você passa pras pessoas uma forma diferente da quadrilha, que tem muita gente que condena, diz que é coisa de vagabundo, que não vê futuro, e eu acho que tem [enfatiza]. Pena que o... o estado, o município não ajudam tanto.

Entrevistadora: Não ajudam?

É, porque era pra ter uma ajuda maior, de um apoio maior, porque às vezes você chega nos cantos pra pedir uma ajuda, pra uma viagem, e o pessoal lhe dá as costas, pensa que quadrilha é só... "não, quadrilha é coisa de vagabundo”, eu acho que não.

Entrevistadora: Você acha que não?

Hum.

Entrevistadora: Por que você acha que não é coisa de vagabundo?

Porque... tem... pessoas casadas que dançam, tem... casal de namorado, noivo, pessoal que trabalha[enfatiza $]_{0}$ ) se esforça pra ir, entendeu? Faz de tudo pra ir, se você gosta mesmo você faz de tudo, você se sacrifica. (Pedro, 24 anos, MG).

Entrevistadora: E que consequências tem em sua vida o fato de ser dançarino de quadrilha?

Fora o preconceito de muitas pessoas que não reconhecem o trabalho dos dançarinos, que o espaço é muito pouco aqui em Campina.

Entrevistadora: O preconceito?

Com certeza, o preconceito em relação a... tem grupos que dança que não aceitam dançarinos que dançam em quadrilha, não aceita nos seus grupos, sabendo eles que os melhores dançarinos desses grupos saíram de quadrilhas, mas já que eles têm esse preconceito a gente não pode fazer nada, em relação a.... às outras pessoas é... [pausa] porque [pausa] muitas pessoas não entendem, acham que a gente tá só pra... se "amostrar", pra num... é um tipo de um... quem não faz nada da vida, mas pelo contrário, tem pai de família [enfatiza]), é toda uma estrutura, é todo um... antigamente não, antigamente tudo bem que... antigamente a gente fazia quadrilha de bairro, sem concurso, sem essas coisas aí... hoje a gente cresceu mais e o pensamento é outro.

Entrevistadora: Hoje o pensamento é outro?

Com certeza. (José, 23 anos, MG).

Eu não, num passo por isso, mas tem muitas pessoas aqui que passam pelo fato da cobrança em casa, que tem muitos pais que não querem, que acham que é coisa de gente desocupado, que acham que é uma coisa que não tem futuro, que acham que não vai levar a nada. Então, tem muita gente que passa por isso, que não é o meu caso, que eu tenho total apoio da minha família. (Joana, 22 anos, MG).

Entrevistadora: E que consequências tem em sua vida o fato de ser dançarina?

Olhe, consequências... porque assim, muita gente, hoje em dia, pelo fato de você dizer eu sou dançarina [enfatiza] a de quadrilha, não leva isso a sério, entendeu? Então quando eu digo: "eu sou dançarina" vão pensar outra coisa [enfatiza] .

Entrevistadora: Que outras coisas?

Vão pensar assim, é... que eu não tenho o que fazer, que... eu.... não me dedico a uma coisa séria, sabe? A estudos, a trabalho, mas não é, não é não, porque assim, pra mim dançarino é um... hobby que 
você... gosta, que já vem dentro de você, só que pra muita gente isso é um... um fato assim, de você não querer fazer nada, de você não se dedicar a nada, é como se fosse um nada ser dançarino [enfatiza]

Entrevistadora: Como se fosse um nada?

É, aí... eu acho que... isso traz consequências, porque muita gente vai olhar pra você e vai dizer que você não faz nada da sua vida, um dançarino... não ganha nada [enfatiza] não faz nada, só, isso pra mim é uma conseqüência. (Graça, 20 anos, MG).

As representações sociais de Pedro, José, Joana e Graça são construídas na tentativa de legitimar a atividade de dançarino de quadrilha junina e se defender da afirmação de que ela "é coisa de vagabundo". Nesse sentido, utilizam argumentos em que o tema trabalho é mencionado como um elemento que qualifica a atividade. Portanto, para Pedro, o argumento utilizado é que existem pessoas casadas, que trabalham (e é enfático), que dançam quadrilha e que se esforçam, sacrificam-se, sugerindo que quem se sacrifica não é vagabundo. O sacrifício aparece atrelado ao esforço e ao trabalho.

Já José, para se defender do preconceito, representa a atividade como um trabalho não reconhecido. Os dançarinos de quadrilha junina são discriminados devido ao fato de algumas pessoas os considerarem desocupados, o que também aparece na fala de Joana. Ao mencionar que "pais de família" participam, que há o concurso, José agrega notabilidade a essa atividade.

Graça é mais enfática em relação à discriminação sofrida pelos dançarinos de quadrilha ao declarar que muitas pessoas consideram "um nada ser dançarino", devido ao fato de acharem que ele não "ganha nada", "não faz nada". Os argumentos utilizados por ela para se defender e legitimar a atividade são também muito próximos dos argumentos utilizados pelos demais. Destaca que ser dançarino é um hobby, mas que ela estuda, trabalha e faz "coisas sérias".

A representação da quadrilha enunciada por esses dançarinos põe em evidência a falta de valorização do trabalho não remunerado desses trabalhadores, na medida em que este, exercido como divertimento e fonte de prazer na quadrilha, não é reconhecido socialmente por uma parcela da sociedade local, já que, como afirma Campos (1993, p. 124 citado por Ribeiro \& Léda, 2004, p. 80), "para a concepção dominante, só tem sentido o trabalho bem remunerado".

Ao se defenderem dessa discriminação, os entrevistados constroem representações da atividade de dançarinos, ressaltam valores como responsabilidade e dignidade e, desse modo, se opõem à concepção de trabalho não reconhecido socialmente, aqui nomeado de vagabundagem.

\section{Trabalho que dá prazer}

O termo "trabalho" é empregado em alguns trechos das entrevistas para se referir à atividade de dançarino, como ressaltado nas falas a seguir:

Entrevistadora: E essa questão de participar de concurso, gosta de participar?

Adoro, é ótimo [enfatiza]! A disputa é ótima, apimentada, é... assim porque a gente vê que... não só quando a gente ganha, como quando a gente perde também, que a gente faz um trabalho [enfatiza] pra agradar o público, não só pra os jurados, o público gostando, e a gente, assim a gente vê que a gente fez um bom trabalho mesmo, não tem coisa mais satisfatória não.

Entrevistadora: Não tem nada mais satisfatório?

Não.

Entrevistadora: E como você se sente realizando essa atividade, como você se sente dançando?

Ah! Eu me sinto ótimo, esqueço todos os problemas que eu tenho durante o dia, esqueço do stress, é... fica emocionado, às vezes chora dançando [enfatiza].

Entrevistadora: Às vezes chora? 
Até nas apresentação mesmo, a emoção é... extrema [enfatiza].

Entrevistadora: Como é este choro?

De emoção, devido, devido... a gente ver o trabalho da gente ali, o esforço da gente ali, o stress de um ano a gente ensaiando [enfatiza] pra montar a quadrilha, e... as conseqüências que às vezes a gente passa devido patrocínio, devido... muitas coisas, é muito gratificante, é muita emoção aqui, quando a gente... sabe? [enfatiza] Vai entrar no arraial.

Entrevistadora: É muito gratificante?

Demais, demais. (Tião, 22 anos, MG).

na maioria das vezes as quadrilhas não dão dançam só pela apresentação, hoje em dia tão visando muito concurso.

Entrevistadora: Tão visando muito concurso?

Exatamente, tão visando muito concurso, aí... quando você ver que não é só obrigado ganhar, se você... é... ver seu trabalho sendo reconhecido pelo público, o que vale é aquilo, vitória é conseqüência do trabalho.

Entrevistadora: Então pra você o mais importante é?

A... a... a... como é que se diz, a... o reconhecimento do público, a vitória é uma conseqüência que, porque você tá num concurso, só são aqueles sete jurados, que tá vendo a quadrilha, se pra eles [enfatiza] se eles gostarem da quadrilha, da quadrilha deles, né? porque a gente vai ser classificado, mas se eles não gostarem, e ver um público com mais de mil pessoas, duas mil, três mil pessoas, tem fase, lhe aplaudindo de pé, isso é mais gratificante ainda do que um título.

Entrevistadora: Então a gratificação vem do público?

Vem do público. [Silêncio]. (Rosa, 24 anos, MG).

Entrevistadora: E pra você, o que é ser dançarino de quadrilha?

Rapaz, é muito gratificante.

Entrevistadora: É muito gratificante?

É muito gratificante porque por onde você passa, você vê o olhar das pessoas, o sorriso num olhar, em ver você fazendo um trabalho bonito, mantendo a tradição de Campina Grande. (Emídio, 19 anos, AF).

A gente já tá... já tá chegando no ponto certo, porque a gente já fez várias viagens, é... vários trabalhos, inclusive o último foi para o Banco o Brasil, que... assim, pra mim... o ano passado eu não dancei, mas, como eu já tinha sido dançarina, é... pra mim foi... um trabalho excelente, porque... estava mostrando várias culturas ... mostrando o nome de Campina Grande . . a cada ano a Mistura vai subindo um degrau, e ela vai tipo que empurrando quando tem dificuldade, entendeu? Porque a quadrilha tem sim dificuldades, entendeu? Então a cada ano a gente vai tentando melhorar, entendeu?

Entrevistadora: Que tipos de dificuldades?

Assim, a gente faz um trabalho é... e demora a receber o cachê, porque.. é um trabalho, então a gente tem que receber cachê, certo que a gente dançarino não recebe, mas a quadrilha recebe [enfatiza] então pra ajudar em adereços, vestidos, essas coisas, assim. Quando se participa de um concurso... tem um valor que a gente sempre ganha, a quadrilha que ganha em primeiro, segundo ou terceiro, então assim, demoram a pagar, demoram a depositar, então, é sim um obstáculo, porque chega agora mês de São João, a gente podendo tá com o dinheiro e não, a gente tem que esperar o dinheiro ainda ser depositado. Mas até agora tá indo tudo bem, a gente tá tirando de letra. (Graça, 20 anos, MG).

Nessas falas anteriores, a atividade de dançarino é representada como trabalho, com todos os desdobramentos daí decorrentes, e dentre eles o reconhecimento do público, apesar das dificuldades como enfatiza Graça. 
Levando em consideração as falas que remetem ao prazer proporcionado pela quadrilha, para a realização do trabalho em conjunto, observa-se que o engajamento e a cooperação mobilizados no trabalho como dançarinos de quadrilha resultam em uma forma particular de retribuição, ainda que seja de natureza simbólica, denominada de reconhecimento (Dejours, 2005, 2012). Na verdade, trata-se de um modo particular de reconhecimento do trabalho, através do julgamento do público e da apreciação do júri, que avalia a apresentação da quadrilha. Desse duplo julgamento, tem-se o reconhecimento social do trabalho em relação ao fazer coletivo e à conquista da identidade dos dançarinos.

Para Dejours (2012), "a conquista da identidade no campo social, mediada pela atividade de trabalho, passa pela dinâmica do reconhecimento" (p. 109). Vê-se, assim, nas falas dos dançarinos, uma mobilização gerada espontaneamente pelos integrantes da quadrilha à realização de uma obra em comum. Nisso, segundo o autor citado, consiste a conquista da identidade, na medida em que se relaciona à realização de cada sujeito no campo das relações sociais. Nessas representações, a atividade de dançarino de quadrilha é um trabalho que dá prazer e satisfação:

Entrevistadora: E que consequências tem em sua vida o fato de ser dançarina de quadrilha?

Só consequências boas, num tem consequências ruins, sem contar que é muito bom para a saúde, né?

... mental e física, é muito bom.

Entrevistadora: É bom pra saúde?

É muito bom, excelente tanto mental, como física [pausa]... trabalhar em grupo, você se entrosa, conhece muita gente, visita muitos lugares.

Entrevistadora: As consequências boas são essas?

Boas, só tem boas, não tem consequências ruins, há não ser uma dorzinha aqui, outra ali porque a gente dança muito, mas isso faz parte de dançarino, né? Tudo tem seus prós e seus contras, mas não vejo consequências ruins em dançar não, só consequências boas.

Entrevistadora: E essas coisas boas?

Muito entrosamento, muita gente conhecida, a gente fica mais comunicativo também, conhecer muita gente, essas coisas.

Entrevistadora: Fica mais comunicativo?

Bem mais, né? Você sabe que a gente tá trabalhando, isso é um trabalho, um trabalho... que você se dá, né? Não é aquele trabalho por obrigação, e é um trabalho que você não realiza sozinho, você realiza com inúmeros, com inúmeros... componentes, né? Todo mundo compartilhando, porque se um não tá dando certo, a quadrilha toda vai desandar, então, tem que ter aquele entrosamento em conjunto.

Entrevistadora: E você se dá?

Com certeza. [Silêncio]

Entrevistadora: E como você se sente realizando essa atividade?

Muito bem, contente tenho certeza mesmo [enfatiza] que eu tô... fazendo o que eu gosto, realmente fazendo o que eu gosto. (Zefinha, 22 anos, AF).

Pra mim, o significado de ser dançarino é que... pra mim, é uma profissão, é uma profissão pra gente [enfatiza].

Entrevistadora: É uma profissão?

Uma profissão e tanto [pausa]... pra cada um de nós.

Entrevistadora: Por que é uma profissão? 
Porque é uma coisa que cada um gosta, cada um tem vontade de tá ali dentro, é igual a um trabalho, todo mundo não tem vontade de ter um trabalho? É como a gente, nós também temos vontade de ter aquela... de estar ali dançando, se divertindo. (Tereza, 20 anos, AF).

Zefinha constrói um discurso em que qualifica a atividade, ressaltando que ela só tem consequências boas, inclusive para a saúde física e mental. Banaliza e justifica as dores que sente no corpo quando dança muito: "há não ser uma dorzinha aqui, outra ali porque a gente dança muito, mas isso faz parte de dançarino, né? Tudo tem seus prós e seus contras, mas não vejo consequências ruins em dançar não, só consequências boas."

Ela é enfática, ao definir a atividade de dançarinos como um trabalho, e faz uma diferenciação desse trabalho afirmando que é trabalho onde ela "se doa", denotando, talvez, uma identificação com ele. Acrescenta, ainda, que é um tipo de trabalho que é desenvolvido em grupo e que, consequentemente, requer entrosamento e cooperação entre os componentes. Zefinha destaca que o trabalho de dançarina não é um "trabalho por obrigação". Tereza, por sua vez, afirma que a atividade é "uma profissão", igual a um trabalho e associa o trabalho ao divertimento: "todo mundo não tem vontade de ter um trabalho? É como a gente, nós também temos vontade de ter aquela... de estar ali dançando, se divertindo."

A análise dessas afirmações enunciadas pelos dançarinos coloca em evidência a representação da noção de trabalho na quadrilha. Essas afirmações nos remetem a elementos discutidos por autores como Marcellino (2006), Stevanato (1995) e Albornoz (2004), que entendem que, para a maioria da população, o trabalho não é considerado uma realização pessoal, mas uma obrigação. A atividade de dançarino de quadrilha não se caracteriza um trabalho por obrigação, como apregoa o discurso da tradição judaico-cristã. Ao contrário, os entrevistados enfatizam a importância do entrosamento coletivo, dos efeitos positivos dessa coletividade para a saúde. Em outros termos, o sentido de pertencimento à quadrilha pode ser traduzido como um trabalho que dá prazer. Não é por acaso que os dançarinos fazem essa atribuição, haja vista que a concepção de trabalho de muitos desses entrevistados (fora da quadrilha) não proporciona essa forma de divertimento com responsabilidade, orientada por dedicação e cumprimento de regras da quadrilha. Talvez, pela via do reconhecimento social, como assinalado por Dejours $(2005,2012)$, os entrevistados tenham apontado outros significados para o trabalho, tais como: o desejo de ser reconhecido por outrem, por si mesmo, pela recusa ao tédio e, com isso, buscar meios de superar as dificuldades (sofrimento) e adquirir prazer como dançarinos de quadrilha.

\section{Considerações finais}

A quadrilha junina foi representada como um divertimento, porém essa "diversão" é diferenciada por ser realizada com "responsabilidade", devido às regras existentes nas quadrilhas, tais como o compromisso com os ensaios e os horários a cumprir. Nessas representações, ressalta-se o sentido de construção coletiva e compartilhada dessa atividade de dançarinos.

Observou-se que em alguns relatos o divertimento, representado pelos entrevistados como sinônimo de lazer, é considerado contrário ao trabalho, que é representado como uma obrigação. Ao realizar essa separação, alguns entrevistados construíram suas identidades de trabalhadores que se divertem como dançarinos de quadrilha, um "divertimento com responsabilidade".

O divertimento também é associado ao prazer despertado pela dança em si, como atividade rítmica, e a satisfação em realizar apresentações artísticas por meio das quadrilhas.

A discriminação direcionada aos dançarinos de quadrilha também é ressaltada pelos entrevistados. Segundo eles, são considerados por algumas pessoas e por familiares como 
desocupados, pessoas que não trabalham em algo útil social e economicamente. Considerando a importância que tem o trabalho remunerado na vida moderna, os discursos dos dançarinos respondem a essa discriminação legitimando a atividade que realizam, por meio da representação dessa atividade como um trabalho que gera prazer.

A representação da atividade de dançarino como um trabalho que dá prazer e que não é por obrigação é ressaltada também em outros relatos, que nos conduzem aos sentidos positivos desse tipo de atividade para a saúde, resultantes do reconhecimento social, do compartilhar com os outros e do sentido de realização. Perguntamo-nos, então: Ser dançarino de quadrilhas juninas é um divertimento que é trabalho? Sem a pretensão de responder a essa indagação, posto que correríamos o risco de simplificá-la, arriscamo-nos a afirmar que o trabalho como modo de agir dos humanos sobre o mundo não se opõe necessariamente ao divertimento, nem ao lazer, nem mesmo ao sofrimento.

\section{Referências}

Albornoz, S. (2004). O que é trabalho? (6a ed.). São Paulo, SP: Brasiliense.

Aquino, C. A. B., \& Martins, J. C. O. (2007). Ócio, lazer e tempo livre na sociedade do consumo e do trabalho. Revista Mal-estar e Subjetividade, 7(2), 479-500. Recuperado de: http://pepsic.bvspsi.org.br/scielo.php?script=sci_ arttext\&pid $=$ S151861482007000200013\&lng =pt\&nrm =iso

Belloni, M. L. (2003). A formação na sociedade do espetáculo: gênese e atualidade do conceito. Revista Brasileira de Educação, (22). Recuperado de http://www.scielo.br/scielo.php?script=sci_arttext\&pid=S1413. $24782003000100011 \& \operatorname{lng}=$ en\&nrm $=$ iso\&tlng $=$ pt

Carvalho, M. (2008). Quadrilhas “estilizadas” animam São João de Campina Grande. O Jornal Brasil de Fato. Recuperado de http://www.brasildefato.com.br/v01/quemsomos

Ciampa, A. C. (1984). Identidade. In: S. T. M. Lane \& W. Codo (Org.), Psicologia social: o homem em movimento (pp. 58-75). São Paulo, SP: Brasiliense.

Ciampa, A. C. (2008). A estória do Severino e a história da Severina. São Paulo, SP: Brasiliense.

Dejours, C. (2005). O fator humano. Rio de Janeiro, RJ: Editora FGV.

Dejours, C. (2012). Trabalho vivo: trabalho e emancipação. Tomo 2. Brasília, DF: Paralelo.

Durrive, L., \& Schwartz, Y. (2008). Glossário da ergologia. Laboreal, 4(1), 23-28. Recuperado de http://aboreal.up.pt/ revista/artigo.php?id=48u56oTV6582234396587;63882

Enriquez, E. (2014). O trabalho, essência do homem? O que é o trabalho? Caderno de Psicologia Social do Trabalho, 17 (spe. 1), 163-176.

Fernandes, S. M. (2011). Psicodinâmica do trabalho em uma companhia de dança do ventre (Monografia de Conclusão de Curso). Universidade do Estado do Rio de Janeiro.

Fridman, L. C. (1999). Pós-modernidade: sociedade da imagem e sociedade do conhecimento. História, Ciências, Saúde-Manguinhos, 6(2). Recuperado de http://www.scielo.br/scielo.php?script=sci_arttext\&pid=S0104$59701999000300007 \& \operatorname{lng}=\mathrm{en} \& n r m=\mathrm{iso} \& \operatorname{lng}=\mathrm{pt}$

Guareschi, P. A. (1996). Representações sociais: alguns comentários oportunos. Coletâneas da ANEPP, 1(10), 9-35.

Lang, A. B. S. G., Campos, M. C. S. S., \& Demartini, Z. B. S. (2010). História oral, sociologia e pesquisa: a abordagem do CERU. São Paulo, SP: Humanitas.

Leplat, J. (2013). Les gestes dans l'activité en situation de travail. Pistes, 15(1), 1-19. Recuperado de http://pistes.revues. org/2951

Lima, E. C. A. (2008). A fábrica dos sonhos: a invenção da festa junina no espaço urbano (2a ed.). Campina Grande, PB: EDUFCG.

Marcellino, N. C. (2006). Estudos do lazer: uma introdução (4a ed.). Campinas, SP: Autores Associados.

Minayo, M. C. S. (1996). O desafio do conhecimento: pesquisa qualitativa em saúde (4a ed.). São Paulo, SP: Hucitec. 
Oliveira, F. O. de, \& Werba, G. C. (1998). Representações sociais. In M. G. C. Jacques, M. N. Strey, \& N. M. G. Bernardes (Org.), Psicologia social (pp. 104-117). Petrópolis, RJ: Vozes.

Ribeiro, C. V. S., \& Léda, D. B. (2004). O significado do trabalho em tempos de reestruturação produtiva. Estudos e

Pesquisas em Psicologia, 4(2) 76-83. Recuperado de http://www.e-publicacoes.uerj.br/index.php/revispsi/article/ view/11145/8847

Sá, C. P. (1996). Sobre o núcleo central das representações sociais. Petrópolis, RJ: Vozes.

Stevanato, L. A. (1995). Os significados do trabalho. Viver Psicologia, 3(32), 19-21.

Trigueiro, O. M. (2007). O festival de quadrilhas estilizadas no Parque do Povo. Jornal Intercom Notícias, 3(64). Recuperado de http://revcom.portcom.intercom.org.br/índex.php/jornal/article/viewArticle/3028/2842

\section{Endereço para correspondência}

nataliabezerra_pe@yahoo.com.br, thelma_veloso@yahoo.com.mx

montepinto@ig.com.br

Recebido em: 20/05/2014

Aprovado em: 30/04/2015 